KIRSTI LAUNIS

\title{
Opettajantyön kehittämisestä mallia työelämän aikuiskouluttajille
}

Reijo Miettinen. Oppitunnista oppimistoimintaan, tutkimus opetuksen ja opettajakoulutuksen kehittämisestä Suomen Liikemiesten Kauppaopistossa vuosina 1986-1991. Gaudeamus 1993.

$\mathbf{R}$ eijo Miettisen teos kuvaa ja analysoi opettajien työn kehittämishanketta ja sen jälkitilannetta Suomen Liikemiesten Kauppaopistossa vuosina 1986-1991. Raportti esittää lä- hestymistavan teoreettiset perustelut, työn historiallisen kehityksen, kehittämishankkeen etenemisen ja johtopäätökset (yhdeksän lukua). Tutkimuksessa on raportoitu pitkäaikainen kehittämisprosessi, jonka tuloksena on syntynyt henkilöstökouluttajalle kiinnostavia tuloksia ja oivalluksia.

Miettisen teos kuvaa monelle työelämän, varsinkin julkishallinnon kouluttajalle tuttua murrosaikaa: 1980-luvun alun kognitiivisen kurssididaktiikan myötä innostuttiin rakentamaan koulutushankkeita, joissa yksittäiseen kurssiin 
tai yksittäisen ammattiryhmän koulutusohjelmaan kohdistunut didaktinen kehittäminen osoittautui riittämättömäksi. Työelämän muutospaineet edellyttivät kouluttajilta kognitiivisen kurssididaktiikan ylittäviä ratkaisuja. Liikemiesten Kauppaopiston opetuksen kehittämishankkeessa huomattiin ja alkuvaiheessa, että opetuksen laadun ongelma ei ollut yksinomaan didaktinen vaan koski koko opetuksen ja opettajankoulutuksen työprosessia.

Miettinen osoittaa, että ihmiset esimerkiksi jossain organisaatioissa eivät toimi vain yksilöllisten käsitystensä mukaan. Yhtä hyvin voidaan sanoa, että he toimivat tuossa yhteisössä valitsevien vakiintuneiden käytäntöjen ja sääntöjen mukaan. (s. 10). Tekijä perustelee lähtökohdakseen kehittävän työntutkimuksen, joka "näkee yksilön oppimisen ja kehityksen lähteenä yksilön ja muuttuvan kokonaistoiminnan (instituutioiden) suhteen." (s. 17). Yksilön ja työyhteisön suhde ei ole vain sisäistämistä ja uudelleen tuottamista, vaan kehittymistä osallistumalla toiminnan kehityksen analysointiin, työvälineiden ja yhteistyön muotojen sekä sääntöjen aktiiviseen muuttamiseen.

$\mathbf{N}$ ykyisten toimintatapojen ja niiden ristiriitojen ymmärtämisen edellytys on työn historiallinen analyysi. Kun teoksen historiallisen osuuden vielä yhdistää Miettisen aikaisempaan teokseen Koulun muuttamisen mahdollisuudesta, löytyvät juuret myös kaupallisen alan opettajankoulutukseen ja opetustyön perusristiriitaan - oppitunteihin keskittyvään toimintatapaan. Suomen Liikemiesten Kauppaopiston oppilaiden, merkonomien, muuttuva työn sisältö ja oppitunteihin keskittyvä opetustyö luovat ratkaisua vaativan ristiriidan.

Historiallisesti johdettua ristiriitaa konkretisoivat haastatteluihin perustuvat ohjaavien opettajien käsitykset työstään. Ristiriita tiedostettiin ja sitä oli yritetty ratkaista esimerkiksi eri oppitunteja koordinoimalla (s. 84-87). Opettajien keskinäiset koordinointiyritykset (s. 87) törmäsivät kuitenkin koko toimintajärjestelmän sääntöihin ja tapaan toimia. Ristiriita ei ollut ylitettävissä yksittäisten opettajien yhteistyöponnistuksin. Uutta oli yritetty kehittää, mutta uusien yksittäiskäytäntöjen yhdistäminen vanhoihin toimintatapoihin oli kuitenkin keisarin uudet vaatteet. Esimerkiksi kognitiivinen oppimisnäkemys oli pelkistynyt MOSUK-kaavaksi (motivointi, orientointi, sisäistäminen, ulkoistaminen, kontrollointi), jonka Miettinen kuvaa enemmänkin oppitunnin mekaaniseksi reseptiksi kuin kognitiivisen didaktiikan soveltamiseksi opetustyöhön.

$\mathbf{R}$ aportissa tekijä kuvaa uuden toimintamallin rakentamista ensin laskentatoimessa ja talousmaantiedossa. Luvun 4 loppuosa ja luku 5 sisältävät mielenkiintoista analyysia siitä, loppuuko lyhyt, suppeaan opettajakuntaan kohdistunut kehittämisprojekti sen kummempia jälkiä jättämättä vai laajeneeko se koskemaan laajempaa opettajakuntaa. Projekti jatkui, laajeni ja osoitti samalla työn kehittämisen olevan monimuotoinen ja useita tasoja sisältävä prosessi. Luvut 4-6 sisältävät yksityiskohtaisia kuvauksia hyvin erilaisten aihekokonaisuuksien kehittelystä. Niihin perehtyminen antoi käsityksen sisältöön paneutuvasta työn kehittämisestä, jossa esimerkiksi mekaaninen MOSUK-kaava purkautuu opetuksen didaktiseksi kehittämiseksi. Käytännön esimerkeistä voi löytää monta tasoa ja näkökulmaa, itseäni kiinnostivat eniten orientaatioiden ja erilaisten tehtävien väliset jännitteet.

Luokattomaan tutkintojärjestelmään siirtyminen ja ammattikorkeakouluun suuntautuminen kärjistivät sisällöllis-pedagogisen ja hallinnollisen suunnittelun välistä ristiriitaa hankkeen edetessä. Sisällöllinen suunnittelu on hidasta ja valikoivaa opetuksen laadun jatkuvaa kehittämistä, hallinnollinen suunnittelu taas kattavaa ja nopealla aikavälillä tehtävää. Näitä kahta pyrittiin yhdistämään hieman huonoin tuloksin. Tekijän arvion mukaan käsitteellisiä, ajallisia ja hallinnollisia edellytyksiä ei ollut. Kaikesta huolimatta kehittämistyö oli löytänyt lukuisia uusia toteutumismuotoja.

Miettisen teoksen luvun 8 tulisi kuulua jokaisen henkilöstön kehittämisen parissa työskentelevän lukukokemuksiin. Uusien ja vanhojen toimintatapojen törmääminen on työelämän tämän päivän arkea. Tämän tutkimuksen mukaan tilanne ei ole missään määrin joko-tai -asetelma. Todellista uutta ei välttämättä synny. Uudeksi tarkoitettu ja luultu voi monella tavalla sulaa osaksi vanhaa toimintatapaa: "Kun työvälineitä 
käytetään vailla riittävää yhteyttä tausta-ajatteluun, on niiden sulautuminen olemassaoleviin toimintatapoihin ja vallitsevaan ajatteluun ymmärrettävää ja todennäköistä.” (s. 227).

$\mathbf{T}_{\mathrm{t}}$ utkimuksensa johtopäätöksissä Miettinen toteaa mm. että opettajan työssä aihekokonaisuuksien suunnittelu kehittyi. Sen sijaan työskentelyn painopisteen siirtyminen opettajan toiminnasta oppilaiden oppimisen näkökulmaan jäi keskeneräiseksi. Aihekokonaisuuksien rakentelu ajankohtaisten ja tärkeiksi kehittyneiden ilmiöiden näkökulmasta eteni, sen sijaan merkonomikvalifikaatioiden analysoinnin tavat ja välineet jäivät puutteellisiksi. Ristiriita hallinnollisen ja pedagogisen kehittelyn välillä kärjistyi. Tulosten pohjalta Miettinen on esittänyt omat näkemyksensä opetuksen kehittämiseksi sekä tutkitussa organisaatiossa että yleisemmin opetustyössä.
Monen muun mielenkiintoisen ja tärkeän asian ohessa tekijä painottaa kunnollisen raportoinnin, arvioinnin ja dokumentoinnin merkitystä kokeilevassa kehittämistoiminnassa. Raportit ja dokumentit toimivat työvälineinä ja mahdollistavat jatkuvuuden ja uusien tavoitteiden asettamisen aivan toisella tavalla kuin pelkät suulliset keskustelut ja kuvaukset.

Miettisen teos edellyttää lukijalta paneutumista. Konsulttien valmismalleihin tai ajassa liikkuviin muotivirtauksiin työnsä perustavat työelämän kouluttajat tuskin jaksavat tähän perusteelliseen teokseen paneutua. Niille työelämän aikuiskouluttajille, jotka haluavat ymmärtää työnsä sekä teoreettisia perusteita että yksityiskohtaisia ratkaisuja, teos on antoisa lukukokemus. Hyvää Miettisen raportissa on myös se, että teos ei ole kertakäyttötavaraa. Siihen voi oman organisaationsa koulutus- ja kehittämishankkeiden yhteydessä palata yhä uudelleen. 